Egypt. Acad. J. Biolog. Sci., 4(1):19-23 (2012)

Email: egyptianacademic@yahoo.com

Received: 17/2/2012
C. Physiology \& Molecular Biology

ISSN: 2090-0767

www.eajbs.eg.net

\title{
Degenerate Primed Polymerase Chain Reaction for Detection of Both Nucleopolyhedrovirus and Granulovirus
}

\author{
AlaaEddeen M. Seufi \\ Dept of Entomology, Fac of Science, Cairo Univ, Giza, Egypt, 12613.
}

\begin{abstract}
A technique using the polymerase chain reaction (PCR) was developed for simultaneous detection of the nucleopolyhedrovirus (NPV) and granulovirus (GV). Ninety one and 73 amino acid sequences of polyhedrin and granulin genes were compared in pairwise and multiple alignment sequences. Seven highly conserved DNA sequences within the coding region of the polyhedrin/granulin genes were identified. Four candidate regions were targeted for amplification and consequently one pair of degenerate PCR primers was designed to produce fragments of about 384 bp. The baculoviruses tested by this technique were Autographa californica (AcMNPV), Bombyx mori NPV (BmNPV), Lymantria dispar NPV (LdNPV), Spodoptera littoralis NPV (SpliNPV), S. littoralis GV (SpliGV), Pieris rapae GV (PrGV), and two local GV isolates $\left(\mathrm{GV}_{\mathrm{G} 213}\right.$ and $\left.\mathrm{GV}_{\mathrm{F} 115}\right)$. Furthermore, four randomly chosen PCR products were cloned and sequenced. The sequencing data showed that the four PCR products were fragments of polyhedrin and granulin genes. Conclusively, this technique would be useful in monitoring the environmental fate, distribution of Baculovirus species, release of the wild type and recombinant Baculovirus and quality control studies of Baculovirus insecticides, as well.
\end{abstract}

Keywords: Nucleopolyhedrovirus, Granulovirus, Baculovirus, PCR.

\section{INTRODUCTION}

Baculoviruses have a large circular double-stranded DNA genome ranging from approximately 80 to $180 \mathrm{~kb}$ in size (Blissard and Rohrmann, 1990). The family Baculoviridae is taxonomically divided into two genera, Nucleopolyhedrovirus and Granulovirus (Theilmann et al., 2005). Although Murphy et al. (1995) have reported baculovirus infections in over 600 insect species in the orders: Lepidoptera, Hymenoptera, Diptera, Coleoptera, Neuroptera, Trichopera and Thysanura, as well as in the Crustaceae order Decapoda (shrimps), it is recently confirmed that only those derived from orders Lepidoptera, Hymenoptera, and Diptera are members of the family Baculoviridae (ICTV, 2009). An updated classification of the family Baculoviridae, which includes four genera: Alphabaculovirus (lepidopteran- specific NPV), Betabaculovirus (lepidopteran-specific GV), Gammabaculovirus (hymenopteranspecific NPV) and Deltabaculovirus (dipteran-specific NPV), was thus proposed (Jehle et al., 2006).

Baculoviruses are being extensively studied for their potential use as bioinsecticides around the world and as expression vectors for heterologous gene expression in insect-derived cells, as well as in host caterpillars (Summers and Smith, 1987, Choi et al., 1999, Wood and Robert, 1991). Recently, some nucleopolyhedrovirus has been successfully developed for surface display of recombinant proteins (Rahman and Gopinathan, 2003), and for potential use as gene therapy vectors (Condreay and Kost, 2007; Huser and Hofmann, 2003; Tani et al., 2003). In addition, the commercialization and release of recombinant viruses in the environment 
created the concern that they might cause ecological disturbances, such as displacement of native microorganisms, adverse effects on non-target organisms and the horizontal transfer of DNA into non-target organisms (Leung et al., 1994). For the above mentioned reasons, many authors were interested in developing an accurate and easy diagnostic method for early, reliable and rapid detection of NPV and GV infections (Wang et al., 2000, Christian et al., 2001, Moraes and Maruniak, 2001, Woo, 2001, Ikuno et al., 2004, Lange et al., 2004, Jehle et al., 2006, Murillo et al., 2006, Kundu et al., 2008, Manzán et al., 2008, Galal, 2009, Hewson et al., 2011, Ravikumar et al., 2011, Arneodo et al., 2012). Several methods have been employed to detect wild type or recombinant baculoviruses, such as microscopic diagnosis (Traverner and Connor, 1992), serological techniques (Brown et al., 1982, Naser and Miltenburger, 1983, Webb and Shelton, 1990), radioimmunoassay techniques (Smith and Summers, 1981, Knell et al., 1983), and DNA dot blot hybridization assays (Ward et al., 1987, Keating et al., 1989). The use of these techniques has been limited because they are either tedious and unreliable, or because they utilize radioactive materials. Polyhedrin and granulin are the major matrix proteins of NPVs and GVs. Lepidopteran polyhedrin gene has been repoted to share $50 \%$ amino acid identity with granulin gene (Rohrmann, 1992, Seufi, 2008). Up to date, there was published data on the complete genome sequence of more than 60 baculoviruses (NPVs and GVs). Polyhedrin and granulin are proteins of about 245 to 250 amino acids, and appeared to be the most highly conserved and similar baculovirus proteins. These characteristics lead to the use of polyhedrin and granulin sequences as the base of baculovirus phylogenetic studies (Zanotto et al., 1993), as well as in polymerase chain reaction (PCR) studies. PCR is a highly sensitive technique, which amplifies target DNA sequences and does not employ radioactive material. PCR has been extensively used to detect many organisms such as animal, human, plant and various pathogens. Many authors reported the use of PCR technology to screen baculoviruses in different approaches over the last three decades (Webb et al., 1991, Burand et al., 1992, Kundu et al., 2003, Ikuno et al., 2004, Kundu et al., 2008, Galal, 2009, Manzán et al., 2008, Hewson et al., 2011, Ravikumar et al., 2011, Arneodo et al., 2012).

The aim of the present study was to design degenerate primer set to detect multiple NPVs and GVs, simultaneously, using PCR technique. The present study will be useful tool in studies seeking to rapidly elucidate a polyhedrin/granulin gene structure, to monitor the release of the wild type as well as genetically engineered baculoviruses, and to isolate NPVs and GVs in the natural environment.

\section{MATERIALS AND METHODS \\ Gene sequence data}

All polyhedrin and granulin amino acid (a.a.) sequences available in January 2012 from GenBank, EMBL, and DDBJ were downloaded. 91 polyhedrin and 73 granulin a.a. sequences were aligned using Mega4 or ClustalX software. Neighbour joining trees for polyhedrin and granulin sequences were examined separately using Mega4 and all divergent sequences were excluded. In addition, the alignments were manually corrected by shifting sequences in places for some sequences possessed large spans of unique deletions or insertions which threw off the alignment algorithm. 100\% identical sequences of the same species, with different accession numbers, were represented by only one sequence. 
Selection of highly conserved genome regions for primer design

The term "conserved genomic regions" used here is defined as petidome regions that have most frequently presented a.a. sequences. To identify the highly conserved regions eligible for primer design, pairwise scan for the sequences was performed and point by point alignment output file was produced using Mega4 and/ or ClustalX software. The most frequently presented a.a. in the same coordinate for all sequences of the alignment was detected. The output (FASTA file) was then analyzed by ClustalX software to select candidate conserved regions for primer design. A "candidate region" was defined as a site within the polyhedrin/granulin open reading frame (orf) that had $6+$ a.a. from the 3 ' end and with a a.a. frequency of $0.80+$. Candidate conserved regions were subjected to calculation of redundancy scores and the average dominant base counts. Average dominant base counts were calculated by summing the number of occurrences of the most common base at each position in a window length of $20+$ bases and averaging those counts across all positions in the window.

\section{Primer design}

The distance between conserved regions was taken into account when selecting conserved sites as was the potential for using mixed bases or deoxyinosines, to enhance bonding at variable positions. Standard nucleotides were preferred close to the 3' termini of the oligonucleotide. The different parameters of primer design (length and sequence, GC content, Tm,........etc.) were taken into consideration. A set of degenerate primers common for the whole group was designed. Primers were designed to amplify $384 \mathrm{bp}$ within the orf of polyhedrin/granulin sequence. The species and accession numbers of polyhedrin and granulin a.a. sequences used in this study are listed in Table (1).

Table 1: Baculovirus species (NPV or GV) and accession numbers of the amino acid sequences used in the present study.

\begin{tabular}{|c|c|c|c|c|c|c|c|}
\hline GV Species & Acc\# & GV Species & Acc\# & NPV Species & Acc\# & NPV Species & Acc\# \\
\hline $\begin{array}{l}\text { Adoxophyes } \\
\text { orana }\end{array}$ & AAL02082, & $\begin{array}{l}\text { Harrisina } \\
\text { brillians }\end{array}$ & AAF66610 & $\begin{array}{l}\text { Adoxophyes } \\
\text { honmai }\end{array}$ & BAC67252 & $\begin{array}{l}\text { Hyposidra } \\
\text { talaca }\end{array}$ & AEK86285 \\
\hline $\begin{array}{l}\text { Agrotis } \\
\text { exclamationis }\end{array}$ & AAW49149 & $\begin{array}{l}\text { Helicoverpa } \\
\text { armigera }\end{array}$ & ABY47692 & Agrotis ipsilon & AAY41433 & $\begin{array}{l}\text { Leucoma } \\
\text { salicis }\end{array}$ & AAW66663 \\
\hline $\begin{array}{l}\text { Agrotis } \\
\text { segetum }\end{array}$ & AAS82737 & $\begin{array}{l}\text { Hyphantria } \\
\text { cunea }\end{array}$ & AAW49159 & $\begin{array}{l}\text { Agrotis } \\
\text { segetum }\end{array}$ & AAZ38167 & $\begin{array}{l}\text { Lymantria } \\
\text { xylina }\end{array}$ & ADD73710 \\
\hline $\begin{array}{l}\text { Andraca } \\
\text { bipunctata }\end{array}$ & AAS86810 & $\begin{array}{l}\text { Peridorma } \\
\text { morpontora }\end{array}$ & AAW49162 & $\begin{array}{l}\text { Anagrapha } \\
\text { falcifera }\end{array}$ & AAB53357 & $\begin{array}{l}\text { Malacosoma } \\
\text { disstria }\end{array}$ & AAD00095 \\
\hline $\begin{array}{l}\text { Caloptilia } \\
\text { theivora }\end{array}$ & BAJ24884 & $\begin{array}{l}\text { Phthorimaea } \\
\text { operculella }\end{array}$ & AAM70199 & $\begin{array}{l}\text { Antheraea } \\
\text { pernyi }\end{array}$ & ABF50243 & $\begin{array}{l}\text { Mamestra } \\
\text { configurata }\end{array}$ & AAB51031 \\
\hline $\begin{array}{l}\text { Choristoneura } \\
\text { fumiferana }\end{array}$ & AAC69544 & Pieris rapae & AAR06236 & Bombyx mori & AAA46734 & $\begin{array}{l}\text { Maruca } \\
\text { vitrata }\end{array}$ & ABL75953 \\
\hline $\begin{array}{l}\text { Choristoneura } \\
\text { murinana }\end{array}$ & AAW49153 & $\begin{array}{l}\text { Pieris } \\
\text { brassicae }\end{array}$ & ACJ24910 & $\begin{array}{l}\text { Buzura } \\
\text { suppressaria }\end{array}$ & CAA50194 & $\begin{array}{l}\text { Neodiprion } \\
\text { abietis }\end{array}$ & AAM95580 \\
\hline $\begin{array}{l}\text { Choristoneura } \\
\text { occidentalis }\end{array}$ & ABC61135 & $\begin{array}{l}\text { Plathypena } \\
\text { scabra }\end{array}$ & AAW49165 & $\begin{array}{l}\text { Choristoneura } \\
\text { fumiferana }\end{array}$ & AAA93292 & $\begin{array}{l}\text { Neodiprion } \\
\text { lecontei }\end{array}$ & YP_025198 \\
\hline $\begin{array}{l}\text { Clostera } \\
\text { anachoreta }\end{array}$ & AAW49154 & $\begin{array}{l}\text { Pseudaletia } \\
\text { unipuncta }\end{array}$ & BAF45154 & $\begin{array}{l}\text { Choristoneura } \\
\text { rosaceana }\end{array}$ & AAB51303 & $\begin{array}{l}\text { Neodiprion } \\
\text { sertifer }\end{array}$ & AAQ96378 \\
\hline $\begin{array}{l}\text { Cryptophlebia } \\
\text { leucotreta }\end{array}$ & AAQ21599 & $\begin{array}{l}\text { Scotogramma } \\
\text { trifolii }\end{array}$ & AAW49166 & $\begin{array}{l}\text { Diaphania } \\
\text { pulverulentalis }\end{array}$ & ACS83600 & $\begin{array}{l}\text { Orgyia } \\
\text { leucostigma }\end{array}$ & ABY65727 \\
\hline $\begin{array}{l}\text { Cydia } \\
\text { pomonella }\end{array}$ & AAK70668 & $\begin{array}{l}\text { Spodoptera } \\
\text { frugiperda }\end{array}$ & AAW49167 & $\begin{array}{l}\text { Ecotropis } \\
\text { obliqua }\end{array}$ & AAQ88174 & $\begin{array}{l}\text { Spodoptera } \\
\text { littoralis }\end{array}$ & BAA00824 \\
\hline $\begin{array}{l}\text { Epinotia } \\
\text { aporema }\end{array}$ & AAO14643 & $\begin{array}{l}\text { Spodoptera } \\
\text { litura }\end{array}$ & ABB96246 & $\begin{array}{l}\text { Epiphyas } \\
\text { postvittana }\end{array}$ & AAC72189 & $\begin{array}{l}\text { Spodoptera } \\
\text { litura }\end{array}$ & CAA64211 \\
\hline Erinnyis ello & AAW49155 & $\begin{array}{l}\text { Trichoplusia } \\
\text { ni }\end{array}$ & AAA43834 & $\begin{array}{l}\text { Helicoverpa } \\
\text { armigera }\end{array}$ & AAB 82410 & $\begin{array}{l}\text { Thysanoplusia } \\
\text { orichalcea }\end{array}$ & AAD51629 \\
\hline $\begin{array}{l}\text { Euхоа } \\
\text { ochrogaster }\end{array}$ & AAW49156 & $\begin{array}{l}\text { Xestia } \\
\text { c-nigrum }\end{array}$ & AAB42059 & $\begin{array}{l}\text { Hyposidra } \\
\text { infixaria }\end{array}$ & AEK86286 & $\begin{array}{l}\text { Wiseana } \\
\text { signata }\end{array}$ & AAB97154 \\
\hline
\end{tabular}




\section{Viruses, cell lines and insects}

The nucleopolyheroviruses and granulovirus tested in this study were as follows: Autographa californica (AcMNPV), Bombyx mori NPV (BmNPV), Lymantria dispar NPV (LdNPV), Spodoptera littoralis NPV (SpliNPV), S. littoralis GV (SpliGV), Pieris rapae GV (PrGV), and two local $\mathrm{GV}$ isolates $\left(\mathrm{GV}_{\mathrm{G} 213}\right.$ and $\left.\mathrm{GV}_{\mathrm{F} 115}\right)$. The $A c \mathrm{MNPV}$ and $\mathrm{BmNPV}$ were propagated in $S f 9$ cells maintained at $27^{\circ} \mathrm{C}$ in a TC100 medium (Gibco-BRL, USA) that was supplemented with $10 \%$ fetal bovine serum (Gibco-BRL, USA). The SpliNPV, $G_{\mathrm{G} 213}$ and $\mathrm{GV}_{\mathrm{F} 115}$ and $L d \mathrm{NPV}$ were propagated in $S$. littoralis and L. dispar larvae, respctively. Routine cell culture maintenance and virus production procedures were carried out according to O'Reilly et al. (1992). Insect colonization and maintenance of the cotton leafworm, Spodoptera littoralis, was done in the insectary of Department of Entomology, Faculty of Science, Cairo University under highly controlled conditions from 1995 to date. The colony was maintained in the laboratory according to Seufi (2008). These insects were used for viral propagation and purification assays.

\section{Virus DNA purification}

Virus DNA was extracted from purified and semipurified viruses collected from infected cells and from insect larvae, as well. Total genomic DNA was also extracted from insect larvae. The virus isolates were successfully propagated and purified following the method described by Lacey et al. (2002). To extract virus DNA, purified or semipurified viruses were resuspended in a $0.1 \mathrm{M}$ sodium carbonate solution $\left(0.1 \mathrm{M} \mathrm{Na}_{2} \mathrm{CO}_{3}, 0.17 \mathrm{M} \mathrm{NaCl}\right.$, 0.01 M EDTA, $\mathrm{pH}$ 10.9), and incubated at $\quad 37^{\circ} \mathrm{C}$ overnight with a final concentration of $0.5 \mathrm{mg} / \mathrm{ml}$ of proteinase $\mathrm{K}$ (Sigma, USA) and $1 \%$ of SDS. A further extraction with phenol and chloroform: isoamylalcohol (24:1) was performed and the DNA was ethanolprecipitated. The DNA was resuspended in a TE buffer $(10 \mathrm{mM}$ Tris- $\mathrm{HCl}, 1 \mathrm{mM}$ EDTA, pH 8.0).

\section{PCR amplification}

PCR amplification was performed according to Saiki et al. (1988) with minor modifications. Total DNA was extracted from the NPV isolates and the DNA segment was amplified using two sets of primers designed based on conserved a.a. sequences of 91 and 73 different polyhedrin/granulin sequences, representing $28 \mathrm{NPV}$ and $28 \mathrm{GV}$ species. Sequence of the forward and reverse primers used in this study, their length, GC content and base counts were shown in Tables (3 and 4). The total reaction volume was $25 \mu \mathrm{l}$ containing $1 \times \mathrm{PCR}$ buffer (Promega), $1.5 \mathrm{mM} \mathrm{MgCl}_{2}, 200$ $\mu \mathrm{M}$ dNTPs, $2.5 \mathrm{U}$ Taq DNA polymerase (Promega), $50 \mathrm{pmol}$ of each primer and $30 \mathrm{ng}$ of template DNA. The amplification program used was $7 \mathrm{~min}$ at $94^{\circ} \mathrm{C}$ (hot start), $30 \mathrm{sec}$ at $94{ }^{\circ} \mathrm{C}, 1 \mathrm{~min}$ at $53{ }^{\circ} \mathrm{C}$ and $1 \mathrm{~min}$ at $72{ }^{\circ} \mathrm{C}$ for 30 cycles followed by one cycle of $72{ }^{\circ} \mathrm{C}$ for 10 min. PCR amplification was carried out in a DNA thermal cycler (Model 380 A, Applied Biosystems, CA, USA).

\section{RESULTS \\ Selection of candidate conserved region for primer design}

Alignment of the selected polyhedrin/granulin sequences were used as a guide to enable identification of conserved regions of the sequence to be used in the design of degenerate primers for PCR. No potentially useful conserved sites were identified in the first complete multiple alignment, utilizing all available sequences in GenBank, EMBL, and DDBJ databases. However, once divergent sequences were removed, seven conserved regions were identified. Two candidate regions (from 51 to 58 and 171 to 191 relative to the Adoxophyes honmai NPV polyhedrin (Acc\# BAC67252) with relatively low levels of degeneracy were selected to design primers (Table 2). One set of degenerate PCR primers (PolG91F and PolG91R) was designed from these regions. 
Table 2: Number, length and location of the identified conserved regions in the polyhedrin/granulin amino acid sequences used in this study. Locations were determined in relation to the Adoxophyes honmai NPV polyhedrin gene (Acc\# BAC67252). The candidate conserved regions were determined using pairwise and multiple sequence alignments.

\begin{tabular}{|c|c|c|}
\hline Conserved region & Location & Length (a.a.) \\
\hline 1 & $51-58^{*}$ & 8 \\
2 & $74-80$ & 7 \\
3 & $100-107$ & 8 \\
4 & $137-142$ & 6 \\
5 & $171-179^{*}$ & 9 \\
6 & $195-203$ & 9 \\
7 & $211-217$ & 8 \\
\hline
\end{tabular}

* The chosen candidate conserved regions for primer design.

\section{Primer Selection}

The PolG91F and PolG91R primers were designed to amplify $384 \mathrm{bp}$ within the polyhedrin/granulin sequences. Sequences of the PolG91F and PolG91R primers and the base count of the respective viral DNAs are shown in Tables (3 and 4). Degenerate sites were considered as low base by base frequency was produced by multiple alignment of the candidate regions. The primers were selected on the basis of having relatively low levels of degeneracy. The bases represented in lower than $5 \%$ in the base count were not considered in designing the primers (Tables 3 and 4). To compensate for the primer multiplicity, a slightly higher primer concentration $(50$ pmol per $25 \mu \mathrm{l}$ reaction) was used in the PCR.

Table 3: Sequence and base counts of the forward primer based on the first candidate conserved region of polyhedrin/granulin sequences. Base count less than $5 \%$ was neglected in primer design.

\begin{tabular}{|c|c|c|c|c|c|c|c|c|c|c|c|c|c|c|c|c|c|c|c|c|}
\hline \multirow{2}{*}{$\begin{array}{l}\text { Base } \\
\text { count }\end{array}$} & \multicolumn{20}{|c|}{ Forward primer (5`---3`) } \\
\hline & $\mathrm{V}$ & $\mathrm{G}$ & $\mathrm{G}$ & $\mathrm{D}$ & $\mathrm{C}$ & $\mathrm{C}$ & $\mathrm{B}$ & A & A & $\mathrm{R}$ & $\mathrm{A}$ & $\mathrm{Y}$ & $\mathrm{G}$ & $\mathrm{K}$ & $\mathrm{R}$ & A & $\mathrm{C}$ & G & G & $\mathrm{C}$ \\
\hline $\mathrm{C}$ & 136 & 153 & 152 & & 155 & 157 & 60 & & 3 & & 1 & 91 & 2 & 2 & & 1 & 156 & 4 & 4 & 162 \\
\hline $\mathrm{G}$ & 13 & 4 & 4 & 71 & 4 & 1 & 89 & 4 & 3 & 86 & 1 & 1 & 158 & 46 & 66 & 1 & 4 & 156 & 156 & \\
\hline $\mathrm{A}$ & 15 & 3 & 4 & 56 & 3 & 3 & & 160 & 154 & 78 & 160 & 2 & 1 & 1 & 98 & 161 & 1 & 2 & & 2 \\
\hline $\mathrm{T}$ & & 4 & 4 & 37 & 2 & 3 & 13 & & 4 & & 2 & 70 & 3 & 115 & & 1 & 3 & 2 & 1 & \\
\hline
\end{tabular}

$\mathrm{V}=\mathrm{G}, \mathrm{A}$ or $\mathrm{C}, \mathrm{D}=\mathrm{A}, \mathrm{T}$ or $\mathrm{G}, \mathrm{B}=\mathrm{C}, \mathrm{G}$ or $\mathrm{T}, \mathrm{R}=\mathrm{A}$ or $\mathrm{G}, \mathrm{Y}=\mathrm{C}$ or $\mathrm{T}, \mathrm{K}=\mathrm{G}$ or $\mathrm{T}$.

Table 4: Sequence and base counts of the reverse primer based on the fifth candidate conserved region of polyhedrin/granulin sequences. Base count less than 5\% was neglected in primer design.

\begin{tabular}{|c|c|c|c|c|c|c|c|c|c|c|c|c|c|c|c|c|c|c|}
\hline \multirow{2}{*}{$\begin{array}{l}\text { Base } \\
\text { count }\end{array}$} & \multicolumn{18}{|c|}{ Reverse primer ( $\left.5^{`}--3^{\prime}\right)$} \\
\hline & $\mathrm{C}$ & $\mathrm{D}$ & $\mathrm{B}$ & $\mathrm{T}$ & $\mathrm{T}$ & $\mathrm{S}$ & $\mathrm{K}$ & $\mathrm{G}$ & $\mathrm{T}$ & $\mathrm{A}$ & $\mathrm{Y}$ & $\mathrm{M}$ & $\mathrm{R}$ & $\mathrm{D}$ & A & $\mathrm{C}$ & $\mathrm{G}$ & $\mathrm{G}$ \\
\hline $\mathrm{C}$ & 159 & 4 & 54 & 4 & & 90 & & 1 & 1 & 2 & 93 & 121 & & 4 & & 160 & 3 & \\
\hline $\mathrm{G}$ & 1 & 56 & 43 & 2 & & 67 & 117 & 158 & 1 & 1 & 3 & 2 & 65 & 66 & 2 & 1 & 161 & 163 \\
\hline A & 2 & 43 & 2 & & 1 & 3 & & 3 & 1 & 161 & 4 & 41 & 98 & 43 & 159 & 1 & & 1 \\
\hline $\mathrm{T}$ & 2 & 61 & 65 & 158 & 163 & 4 & 47 & 2 & 159 & & 64 & & 1 & 51 & 1 & & & \\
\hline
\end{tabular}

$\mathrm{D}=\mathrm{A}, \mathrm{T}$ or $\mathrm{G}, \mathrm{B}=\mathrm{C}, \mathrm{G}$ or $\mathrm{T}, \mathrm{S}=\mathrm{C}$ or $\mathrm{G}, \mathrm{K}=\mathrm{G}$ or $\mathrm{T}, \mathrm{Y}=\mathrm{C}$ or $\mathrm{T}, \mathrm{M}=\mathrm{C}$ or $\mathrm{A}, \mathrm{R}=\mathrm{A}$ or $\mathrm{G}$.

\section{Experimental verification}

Two degenerate primers were designed to anneal within the orf of polyhedrin/granulin sequence (PolG91F and PolG91R). The degenerate PCR primer set successfully amplified the expected polyhedrin/granulin DNA fragment (384 bp) from the AcMNPV, BmNPV, LdNPV, SpliNPV as well as from SpliGV, $\operatorname{PrGV}, \mathrm{GV}_{\mathrm{G} 213}$ and $\mathrm{GV}_{\mathrm{F} 115}$ isolates. Few non-specific amplification products were observed for the tested viruses (Fig. 1). Four randomly chosen PCR products (2 NPV and $2 \mathrm{GV}$ ) were cloned into $p$ GEM-T vector and sequenced using the universal $\mathrm{M}_{13}$ primers and using PolG91F and PolG91R, as well. The sequencing results showed that the four PCR products were fragments of polyhedrin and granulin genes showing a high percentage of similarity (up to $85 \%$ ). 


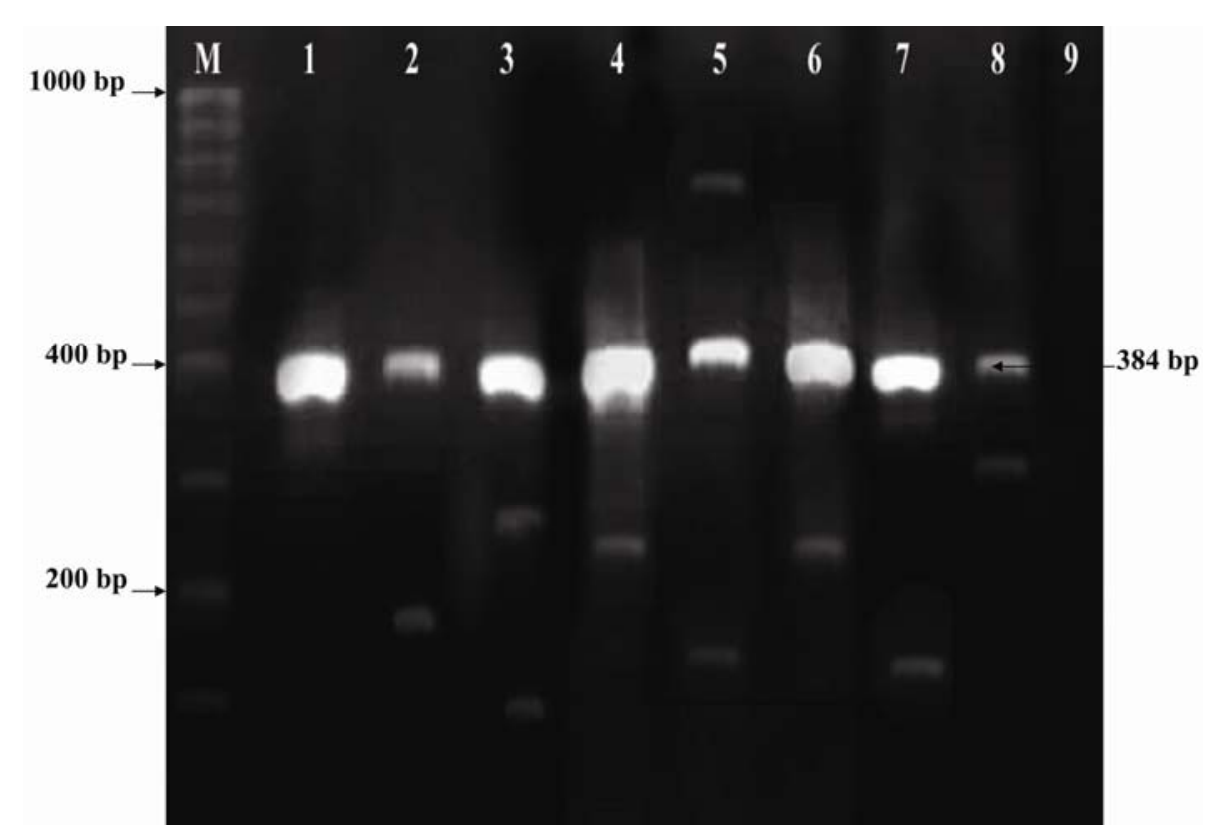

Fig. (1): PCR results showing the amplification of $\sim 384$ bp fragment in the polyhedrin/ granulin genes coding region of eight baculovirus isolates. M: 100 bp ladder DNA marker, lanes 1: AcMNPV, 2: BmNPV, 3: LdNPV, 4: SpliNPV. Lanes 5-8: SpliGV, $\operatorname{PrGV}, \mathrm{GV}_{\mathrm{G} 213}$ and $\mathrm{GV}_{\mathrm{F} 115}$, respectively. Lane 9: Negative control (PCR mix without template DNA). The size of the bands is shown in bp.

\section{DISCUSSION AND CONCLUSION}

Polyhedrin and granulin genes of NPVs and GVs encode for the matrix protein of the virus occlusion body and are considered of the most conserved baculovirus genes (Jehle, 2004). These genes were proved to be the most suitable genes in baculoviruses for developing generic amplification techniques (Woo, 2001). Seufi (2008) characterized a highly conserved polyhedrin region of $405 \mathrm{bp}$ molecular size. He reported significant alignment with $11 \mathrm{GV}$ granulins. In addition, lepidopteran polyhedrin genes show about a 50\% amino acid identity with granulovirus granulins, and a $40 \%$ identity with hymenopteran NPV polyhedrin (Rohrmann, 1992). These high similarities could enhance the strategy to design universal primers for detection of both NPV and GVinfections. The advantage of such approach is that it utilized all NPV and GV polyhedrin/granulin sequences available in the international databases (91 and 73 sequences) and simple public software programs to select optimal candidate regions for PCR amplification.
Such approach is unlikely to produce significant bias towards any one species, especially if there is no bias in the multiple sequence alignment, on which the approach was based. These primers make it possible to efficiently amplify DNA from many NPV and GV species. It also allowed further search for novel NPV and GV isolates. Many published reports that investigated polyhedrin gene depended primarily on a Southern hybridization using probes of the polyhedrin gene of other previously identified viruses. However, this technique is efficient only if the similarity between polyhedrin genes of the target NPV and probe NPV is high. Therefore, many limitations will arise when the study based mainly on Southern technique. One major limitation is that this technique requires multiple probes of various NPVs for detection of baculovirus. Also, traditional serological methods based on neutralization and fixed cell ELISA have proven to be effective for identifying baculoviruses (Brown et al., 1982). However, difficulties in interpreting antigenic cross reactivity and/ or failure to identify 
relatively close antigenic relationships were common complains in this technology. Moreover, serological techniques are time consuming, require highly experienced personnel and are less precise than nucleotide sequence determination. Generally, the use of PCR technology for virus detection, identification and characterization is a basic tool in many virology laboratories (Moraes and Maruniak, 1997, Moraes et al., 1999, Wang et al., 2000, Christian et al., 2001, Moraes and Maruniak, 2001, Woo, 2001, Ikuno et al., 2004, Lange et al., 2004, Jehle et al., 2006, Murillo et al., 2006, Kundu et al., 2008, Manzán et al., 2008, Galal, 2009, Hewson et al., 2011, Ravikumar et al., 2011, Arneodo et al., 2012). Indeed, a good set of primers for simultaneous NPV and GV detection is a powerful tool for large Baculovirus sample screening. PCR technique is preferred because it is easy, fast, sensitive and reliable, as well. In addition, very small amount of DNA is needed, and it does not utilize radioactive materials. Many attempts to detect NPV from soil and insects have been made using PCR techniques, but it was limited to narrow NPV species (Webb et al., 1991, Moraes and Maruniak, 1997, Moraes et al., 1999). Woo (2001) designed a pair of degenerate primers to detect multiple NPVs using PCR. One major problem with degenerate primers is that the concentration of some permutations in the mixture is so small that amplification is effectively inhibited (due to their great multiplicity). It was believed that the redundancy of PolG91F and PolG91R primers was insufficient to cause this problem. In the progress of this issue, Ikuno et al. (2004) applied new PCR protocol for evaluating and monitoring Bombyx mori NPV-infection, and Ravikumar et al. (2011) developed a multiplex polymerase chain reaction for the simultaneous detection of microsporidians, nucleopolyhedrovirus, and densovirus infecting silkworms. In the same time, Hewson et al. (2011) reported the detection of NPV in terrestrial and marine habitats using PCR. On the other hand, Kundu et al. (2003) and Kundu et al. (2008) developed a PCR protocol to detect the GVs of Adoxophyes orana and Cydia pomonella in their hosts. Manzán et al. (2008) developed a multiplex PCR protocol for the quality control of Epinotia aporema granulovirus production. Recently, Arneodo et al. (2012) developed a realtime PCR approach for detection and and kinetic analysis of Epinotia aporema granulovirus in its host.

Up to date, no reports were published on the development of PCR protocol that can detect NPV and GV simultaneously. The capacity of PolG91F and PolG91R primers to efficiently amplify all tested NPVs and GVs made them an invaluable diagnostic and taxonomic tool for virology. The ability of these primers to amplify DNA from local isolates of GVs may demonstrate their capacity to define novel NPVs and GVs species. In summary, the PCR primer set employed in this study was chosen from highly conserved regions within the polyhedrin/granulin region. Therefore, the possibility of amplification of multiple Baculovirus species was more enhanced. The present study introduced a highly sensitive method for multiple and simultaneous Baculovirus detection. Higher sensitivity and cost-efficiency enabled the researcher to identify the structure of the polyhedrin and granulin genes rapidly. The amplification of highly specific and abundant products obtained in this study suggested that this method might be useful to detect both NPVs and GVs with very low amounts of DNA in the environment.

Conclusively, the method described in this paper is considered universal, powerful, and could be used in the future to study the environmental fate of wild type or genetically modified recombinant Baculovirus. It may be useful in quality 
control studies of Baculovirus insecticides, as well.

\section{REFERENCES}

Arneodo, J.; König, G.; Berretta, M.; Di Rienzo, J.; Taboga, O.; Sciocco-Cap, A. (2012): Detection and kinetic analysis of Epinotia aporema granulovirus in its lepidopteran host by real-time PCR. Arch. Virol., 157(3): 405-409.

Blissard, G.; Rohrmann, G. (1990): Baculovirus diversity and molecular biology. Annu. Rev. Entomol., 35:127-155.

Brown, D.; Allen, C.; Bignell, G. (1982): The use of a protein A conjugate in an indirect enzyme-linked immunosorbent assay (ELISA) of four closely related baculoviruses from Spodoptera species. J. Gen. Virol., 62:375-378.

Burand, J.; Horton, H.; Retnasami, S.; Elkington, J. (1992): The use of polymerase chain reaction and shortwave UV irradiation to detect baculovirus DNA on the surface of gypsy moth eggs. J. Virol. Methods, 36:141-150.

Christian, P.; Gibb, N.; Kasprzak, A.; Richards, A. (2001): A rapid method for the identification and differentiation of Helicoverpa nucleopolyhedroviruses (NPV Baculoviridae) isolated from the environment. J. Virol. Methods, 96:51-65.

Condreay, J.; Kost, T. (2007): Baculovirus expression vectors for insect and mammalian cells. Curr. Drug Targets 8:1126-1131.

Galal, F. (2009): Universal Primer for Early and Rapid Detection of Nucleopolyhedroviruses of Multiple Species Using Polymerase Chain Reaction. Egypt. Acad. J. biolog. Sci., 1(1): 57-64.

Hewson, I.; Brown, J.; Gitlin, S.; Doud, D. (2011): Nucleopolyhedrovirus detection and distribution in terrestrial, freshwater, and marine habitats of Appledore Island, Gulf of Maine. Microb Ecol., 62(1): 48-57.

Huser, A.; Hofmann, C. (2003): Baculovirus vectors: novel mammalian cell gene-delivery vehicles and their applications. Am. J. Pharmacogenomics, 3: 53-63.

Ikuno, A; Margatho, L.; Harakava, R.; Akamatsu, M.; Martins, E.; Porto, A.; Ferreira, V. (2004): Direct application of the new PCR protocol for evaluation and monitoring of Bombyx mori infection by nucleopolyhedrovirus. Arq. Inst. Biol., 71 (3): 309-315.

International Committee on Taxonomy of Viruses (2009): Virus Taxonomy: 2009 Release.

Jehle, J. (2004): The Mosaic Structure of the Polyhedrin Gene of the Autographa californica Nucleopolyhedrovirus (AcMNPV). Virus Genes, 29 (1):5-8.

Jehle, J.; Blissard, G.; Bonning, B.; Cory, J.; Herniou, E.; Rohrmann, G.; Theilmann, D.; Thiem, S.; Vlak, J. (2006): On the classification and nomenclature of baculoviruses: a proposal for revision. Arch. Virol., 151:1257-1266.

Keating, S.; Burand, J.; Elkington, J. (1989): DNA hybridization assay for detection of gypsy moth nuclear polyhedrosis virus in infected gypsy moth (Lymantria dispar L.) larvae. Appl. Environ. Microbiol., 55:27492754.

Knell, J.; Summers, M.; Smith, G. (1983): Serological analysis of 17 baculoviruses from subgroup A and B using protein blot immunoassay. Virol., 125:381-392.

Kundu, J.; Stará, J.; Kocourek, F.; Pultar, O. (2003): Polymerase chain reaction assay for Cydia pomonella granulovirus detection in Cydia pomonella population. Acta Virol., 47(3):153-157. 
Kundu, J.; Zichová, T.; Stará, J.; Kocourek, F. (2008): Detection of Adoxophyes orana granulovirus in Adoxophyes orana by PCR. Acta Virol., 52(3):187-188.

Lacey, L.; Vail, P.; Hoffmann, D. (2002): Comparative activity of baculoviruses against the codling moth Cydia pomonella and three other tortricid pests of tree fruit. $J$. Invertebr. Pathol., 80:64-68.

Lange, M.; Wang, H.; Zhihong, H.; Jehle, J. (2004): Towards a molecular identification and classification system of lepidopteran-specific baculoviruses. Virol., 325:36-47.

Leung, K.; England, L.; Cassidy, M.; Trevors, J.; Weir, S. (1994): Microbial diversity in soil: effect of releasing genetically engineered microorganisms. Mol. Ecol., 3:413422.

Manzán, M.; Aljinovic, E.; Biedma, M.; Sciocco-Cap, A.; Ghiringhelli, P; others (2008): Multiplex PCR and quality control of Epinotia aporema granulovirus production. Virus Genes, 37(2): 203-211.

Moraes, R.; Maruniak, J. (2001): Detection and identification of multiple baculoviruses using the polymerase chain reaction (PCR) and restriction endonuclease analysis. Mol. Cells, 11:334-40.

Moraes, R.; Maruniak, J.; Funderburk, J. (1999): Methods for detection of Anticarsia gemmatalis nucleopolyhedrovirus DNA in soil. Appl. Environ. Microbiol., 65:23072311.

Murillo, R.; Munoz, D.; Williams, T.; Mugeta, N.; Caballero, P. (2006): Application of the PCR-RFLP method for the rapid differentiation of Spodoptera exigua nucleopolyhedrovirus genotypes. $J$. Virol. Methods, 135:1-8.

Murphy, F.; Fauquet, C.; Bishop, D.; Ghabrial, S.; Jarvis, A.; Martinelli, G.; Mayo, M.; Summers, M. (1995):
Virus Taxonomy. Springer Verlag, Vienna.

Naser, W.; Miltenburger, H. (1983): Rapid baculovirus detection, identification, and serological classification by western blottingELISA using a monoclonal antibody. J. Gen. Virol., 64:639-647.

O'Reilly, D.; Miller, L.; Luckow, V. (1992): Baculovirus expression vectors: a laboratory manual. Freeman, New York, USA.

Rahman, M.; Gopinathan, K. (2003): Bombyx mori nucleopolyhedrovirusbased surface display system for recombinant proteins. J. Gen. Virol., 84: 2023-2031.

Ravikumar, G.; Raje Urs, S.; Vijaya Prakash, N.; Rao, N.; Vardhana, K. (2011): Development of a multiplex polymerase chain reaction for the simultaneous detection of microsporidians, nucleopolyhedrovirus, and densovirus infecting silkworms. J. Invertebr. Pathol., 107 (3):193-197.

Rohrmann, G. (1992): Baculovirus structure proteins. J. Gen. Virol., 73:749-761.

Saiki, R.; Gelfand, D.; Stoffel, S.; Scharf, S.; Higuchi, R.; Horn, G.; Mullis, K.; Erlich, H. (1988): Primer-directed enzymatic amplification of DNA with a thermostable DNA polymerase. Science, 239:487-491.

Seufi, A. (2008): Characterization of an Egyptian Spodoptera littoralis nucleopolyhedrovirus and a possible use of a highly conserved region from polyhedron gene for nucleopolyhedrovirus detection. Virol. J., 5:13.

Smith, G.; Summers, M. (1981): Application of a novel radioimmunoassay to identify baculovirus structural proteins that share interspecies antigenic determinants. J. Virol., 39:125-137.

Tani, H.; Limn, C.; Yap, C.; Onishi, M.; Nozaki, M.; Nishimune, Y.; Okahashi, N.; Kitagawa, Y.; Watanabe, R.; other authors (2003). 
In vitro and in vivo gene delivery by recombinant baculoviruses. J. Virol., 77: 9799-9808.

Theilmann, D.; Blissard, G.; Bonning, B.; Jehle, J.; O'Reilly, D.; Rohrmann, G.; Thiem, S.; Vlak, J. (2005): Baculoviridae. In Virus Taxonomy: Eighth Report of the International Committee on Taxonomy of Viruses, pp. 177-185. Edited by C. M. Fauquet, M. A. Mayo, J. Maniloff, U. Desselberger \& L. A. Ball. San Diego: Elsevier.

Traverner, M.; Connor, E. (1992): Optical enumeration technique for detection of baculoviruses in the environment. Environ. Entomol., 21:307-313.

Wang, C.; Yang, H.; Liu, H.; Kou, G.; Lo, C. (2000): Nested polymerase chain reaction and in situ hybridization for detection of nucleopolyhedrosis. J. Virol. Methods, 84:65-75.

Ward, V.; Fleming, S.; Kalmakoff, J. (1987): Comparison of a DNA-DNA dotblot hybridization assay with light microscope and radioimmunoassay for the detection of a nuclear polyhedrosis virus. J. Virol. Methods, 15:65-73.

Webb, A.; Bradley, M.; Phelan, S.; Wu, J.; Gehrke, L. (1991): Use of the polymerase chain reaction for screening and evaluation of recombinant baculovirus clones. Biotechniques, 4:512-519.

Webb, S.; Shelton, A. (1990): Effect of age structure on the outcome of viral epizootics in field populations of imported cabbageworm (Lepidoptera: Pieridae). Environ. Entomol., 19:111116.

Woo, S. (2001): Rapid detection of multiple nucleopolyhedroviruses using polymerase chain reaction. Mol. Cells, 11:334-40.

Zanotto, P.; Kessing, B.; Maruniak, J. (1993): Phylogenetic interrelationships among baculoviruses: evolutionary rates and host associations. J. Invertebr. Pathol., 62:147-164.

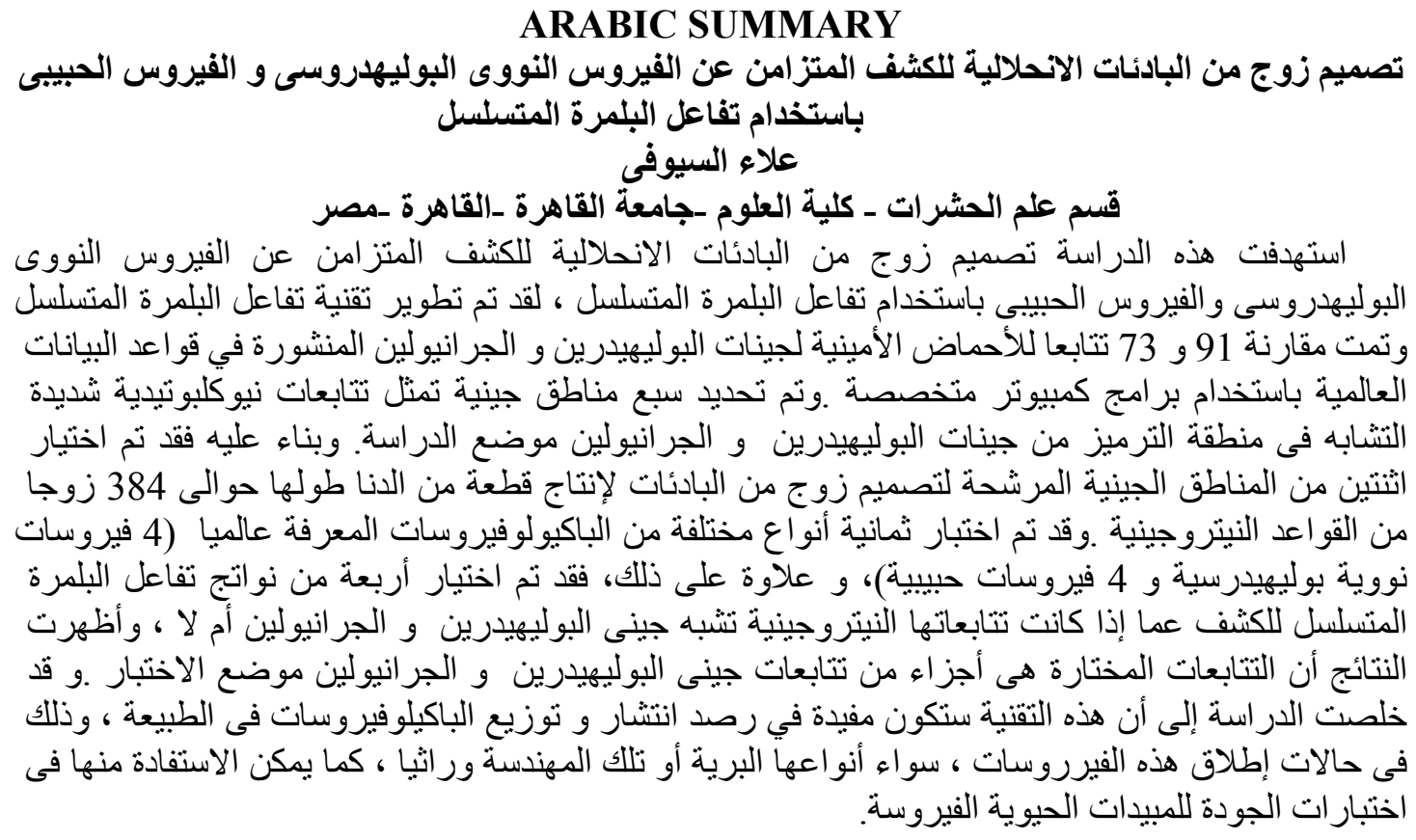

